\title{
ACE2 Expression is elevated in Airway Epithelial Cells from aged and male donors but reduced in asthma.
}

\author{
Peter AB Wark ${ }^{1,3}$, Prabuddha S. Pathinayake ${ }^{1}$, Gerard Kaiko ${ }^{2}$, Kristy Nichol ${ }^{1}$, Ayesha Ali², Ling Chen², \\ Erika N Sutanto ${ }^{6,7}$, Luke W Garratt ${ }^{6}$, Sukhwinder S. Sohal ${ }^{5}$, Wenying Lu' ${ }^{5}$, Mathew S. Eapen ${ }^{5}$, \\ Christopher Oldmeadow ${ }^{10}$, Nathan Bartlett ${ }^{2}$, Andrew Reid ${ }^{2}$, Punnam Veerati ${ }^{1}$, Alan C-Y.Hsu ${ }^{1}$, Kevin \\ Looi $^{6,7}$, Thomas losifidis: ${ }^{6,7,8}$, Stephen M Stick: ${ }^{6,8,9}$, Philip M. Hansbro ${ }^{4}$, and Anthony Kicic ${ }^{6,7,8,9}$
}

Author Affiliations:

1Priority Research Centre for Healthy Lungs, Hunter Medical Research Institute and School of Medicine and Public Health, University of Newcastle, Newcastle, New South Wales, Australia.

${ }_{2}$ Priority Research Centre for Healthy Lungs, Hunter Medical Research Institute and School of Biomedical Sciences and Pharmacy, University of Newcastle, Newcastle, New South Wales, Australia.

3Department of Respiratory and Sleep Medicine, John Hunter Hospital, Newcastle, New South Wales, Australia.

4Centre for Inflammation, Centenary Institute, and Faculty of Science, University of Technology Sydney, Sydney, New South Wales, Australia

5Respiratory Translational Research Group, Department of Laboratory Medicine, School of Health Sciences, College of Health and Medicine, University of Tasmania, Launceston, Tasmania, Australia

6Telethon Kids Institute, University of Western Australia, Western Australia, Australia 7School of Public Health, Curtin University, Western Australia, Australia

${ }_{8}$ Centre for Cell Therapy and Regenerative Medicine, School of Medicine and Pharmacology, University of Western Australia, Western Australia, Australia

9Department of Respiratory and Sleep Medicine, Perth Children's Hospital, Western

Australia, Australia

10 Hunter Medical Research Institute, Newcastle, New South Wales, Australia.

\section{Impact}

ACE2 is the primary receptor for SARS-COV-2. We demonstrate that lower airway expression of ACE2 is increased in older adults and males. We also find that lower ACE2 expression in epithelial cells occurs in people with asthma and is associated with reduced Furin expression and increased ADAM-17 expression. This may explain at least in part the relative sparing of people with asthma from severe COVID-19 disease. 
medRxiv preprint doi: https://doi.org/10.1101/2020.07.26.20162248; this version posted July 29,2020 . The copyright holder for this preprint

(which was not certified by peer review) is the author/funder, who has granted medRxiv a license to display the preprint in perpetuity.

\section{Corresponding author:}

Prof Peter AB Wark

Centre for Healthy Lungs, HMRI, University of Newcastle

Lookout Rd New Lambton NSW 2305

AUSTRALIA

Phone; +61 249213470

Fax +6124923469

Email; peter.wark@newcastle.edu.au

\section{Author contributions:}

PW conceived the study, wrote the manuscript. PP, KN, AR, PV, AH performed PCR, analysed results from Newcastle cohort and reviewed the manuscript. AA, LC and GK prepared the IHC slides and reviewed the manuscript. SSS, Wl, ME prepared prepared the IHC slides and reviewed the manuscript. ES, LG prepared and acquired samples from Perth. TI and AK analysed the Perth samples and contributed to the manuscript. CO performed multivariate regression analysis. SS, AK and PMH helped conceive the idea, reviewed the manuscript and assisted with writing.

\section{Word count 3,729}

\section{Running title:}

ACE2 receptor expression is reduced in asthma 
medRxiv preprint doi: https://doi.org/10.1101/2020.07.26.20162248; this version posted July 29, 2020. The copyright holder for this preprint (which was not certified by peer review) is the author/funder, who has granted medRxiv a license to display the preprint in perpetuity.

\section{Abstract}

Rationale: COVID-19 is complicated by acute lung injury, and death in some individuals. It is caused by SARS-CoV-2 that requires the ACE2 receptor and serine proteases to enter airway epithelial cells (AECs).

Objective: To determine what factors are associated with ACE2 expression particularly in patients with asthma and chronic obstructive pulmonary disease (COPD).

Methods: We obtained upper and lower AECs from 145 people from two independent cohorts, aged 2-89, Newcastle $(n=115)$, and from Perth $(n=30)$ Australia. The Newcastle cohort was enriched with people with asthma $(n=37)$ and COPD $(n=38)$. Gene expression for ACE2 and other genes potentially associated with SARS-CoV-2 cell entry were assessed by quantitative PCR, protein expression was confirmed with immunohistochemistry on endobronchial biopsies and cultured AECs.

Results: Increased gene expression of ACE2 was associated with older age $(p=0.02)$ and male sex $(\mathrm{p}=0.03)$, but not pack-years smoked. When we compared gene expression between adults with asthma, COPD and healthy controls, mean ACE2 expression was lower in asthma $(\mathrm{p}=0.01)$. Gene expression of furin, a protease that facilitates viral endocytosis, was also lower in asthma ( $\mathrm{p}=0.02)$, while ADAM-17, a disintegrin that cleaves ACE2 from the surface was increased $(\mathrm{p}=0.02)$. ACE2 protein levels were lower in endobronchial biopsies from asthma patients.

Conclusions: Increased ACE2 expression occurs in older people and males. Asthma patients have reduced expression. Altered ACE2 expression in the lower airway may be an important factor in virus tropism and may in part explain susceptibility factors and why asthma patients are not over-represented in those with COVID-19 complications.

Abstract word count; 250

\section{Key words}

Viral infections

Bronchial asthma

Chronic Obstructive Pulmonary Disease

Pandemics 
medRxiv preprint doi: https://doi.org/10.1101/2020.07.26.20162248; this version posted July 29,2020 . The copyright holder for this preprint

(which was not certified by peer review) is the author/funder, who has granted medRxiv a license to display the preprint in perpetuity.

All rights reserved. No reuse allowed without permission.

\section{Introduction}

In December 2019 an outbreak of a novel respiratory illness, resulting in severe disease and respiratory failure emerged in Wuhan, China and has since spread to become the major pandemic in living memory, now known as coronavirus disease (COVID)-19 (1). The virus responsible was rapidly identified as a previously unknown beta-coronavirus, closely related to severe acute respiratory syndrome-associated coronavirus (SARS-CoV) and is now identified as SARS-CoV-2 $(2,3)$. The virus is known to bind to the Angiotensin-converting enzyme 2 (ACE2) receptor and requires the serine protease TMPRSS2 to cleave the viral spike protein in order to enter a cell (3). This step appears to be facilitated by endosomal proteases such as cathepsin- $\mathrm{L}$ and enhanced by the protein furin $(4,5)$, the virus then enters the host cell by endocytosis.

COVID-19 has had a devastating impact, now infecting more than 5 million and is responsible for at least 334,000 deaths world-wide (WHO reports)(6). Infection begins in the upper respiratory tract and while the majority of people experience a mild disease course 10$15 \%$ have more severe disease with progression to infection of the lower airways, resulting in pneumonia, acute respiratory distress syndrome (ARDS) and death $(7,8)$. People with chronic respiratory disease, especially asthma and chronic obstructive pulmonary disease (COPD) are usually at heightened risk of complications from acute respiratory viral infections (9). This however is not clearly the case with COVID-19, while there appears to be a heightened risk for active smokers $(10,11)$, those with asthma do not appear to be overrepresented. Age and male sex appear to be associated with worse outcomes, and children generally experience only mild illness (12-14). One factor that may predispose to more severe disease and pneumonia is the level of expression of the ACE2 receptor in airway epithelial cells (AECs) of the lower respiratory tract allowing infection to spread more easily from the upper airway. 
medRxiv preprint doi: https://doi.org/10.1101/2020.07.26.20162248; this version posted July 29, 2020. The copyright holder for this preprint

(which was not certified by peer review) is the author/funder, who has granted medRxiv a license to display the preprint in perpetuity.

All rights reserved. No reuse allowed without permission.

We sought to determine the expression of ACE2 and other genes that are crucial for viral entry in primary human AECs in healthy individuals and in people with asthma and COPD.

\section{Methods}

\section{Participants}

Subjects for this study had all been previously and independently recruited to provide upper or lower airway samples for studies of chronic asthma or COPD and comprise two independent cohorts.

Cohort one was recruited in Newcastle (New South Wales, Australia) from adults over the age of 18 years, who underwent bronchoscopy, with endobronchial brushings and biopsies from the third to fourth generation airways (15). Epithelial cells were sub-cultured and subsequently differentiated at air-liquid interface (ALI) (16). The study was approved by Hunter New England Human Research Ethics Committee (Reference No 05/08/10/3.09) and all participants provided written informed consent.

Participants had no history of a clinical chest or upper respiratory tract infection in the previous 6 weeks prior to obtaining lower airway specimens. Healthy controls were nonsmokers, had normal lung function assessed by spirometry, and had no previous history of respiratory disease. Adults with asthma had a physician's diagnosis of asthma with objective evidence of airflow variability or bronchial hyperactivity on provocation challenge. No participants with asthma were current smokers and all had less than a 5 pack-year history of smoking. Those with COPD had evidence of respiratory symptoms in combination with a post bronchodilator FEV 1 of less than $80 \%$ of predicted value and/or a post bronchodilator FEV $1 /$ FVC less than $70 \%$. Participants with COPD could be current or former smokers. A current medical history of cardiovascular disease, hypertension and diabetes were all recorded, along with medication use. 
medRxiv preprint doi: https://doi.org/10.1101/2020.07.26.20162248; this version posted July 29,2020 . The copyright holder for this preprint

(which was not certified by peer review) is the author/funder, who has granted medRxiv a license to display the preprint in perpetuity.

All rights reserved. No reuse allowed without permission.

Cohort two was recruited in Perth (Western Australia, Australia) and were all healthy controls with no history of chronic heart or lung disease. They included children undergoing elective surgery for non-respiratory-related conditions $(n=14 ; 2.4-6.8$ years of age; 7 males $)$ and adult volunteers $(\mathrm{n}=16 ; 25.5-57.1$ years of age; 5 males). They were recruited into the study under Ethics approval by the Perth Children's Hospital Ethics Committee (RGS1470) and St John of Gods Human Ethics Committee (SJOG\#901). Those with recent chest infection were excluded from the study and written consent was then obtained from parents or guardians of children and adult participants. Epithelial samples were obtained and processed as previously described $(17,18)$.

\section{Gene expression by qPCR}

Detailed description of the qPCR is provided in the supplementary methods. Results were calculated using 2- $\Delta \Delta \mathrm{Ct}$ (where $\mathrm{Ct}$ is the threshold cycle) relative to the mean $\Delta \mathrm{Ct}$ of the healthy control group as described previously (19). Details of primers and probes are in the supplementary Table.

\section{Immunohistochemistry}

Formalin-fixed paraffin embedded endobronchial biopsies from subjects from the Newcastle cohort were taken from the third to fourth generation airways. They were sectioned and rehydrated for immunofluorescence analysis. Detailed methods are provided in the supplement methods.

\section{Statistical Analysis}

Data were analysed using Stata software version 15 (StataCorp, College Station, TX, USA) or with Graphpad prism 8. Results are reported as mean (SD) or median (interquartile range), unless otherwise stated. Continuous measures were analysed using Student's T test or oneway analysis of variance (ANOVA) as appropriate. Spearman's correlation coefficients were 
medRxiv preprint doi: https://doi.org/10.1101/2020.07.26.20162248; this version posted July 29, 2020. The copyright holder for this preprint

(which was not certified by peer review) is the author/funder, who has granted medRxiv a license to display the preprint in perpetuity.

All rights reserved. No reuse allowed without permission.

calculated for univariate association between continuous variables. Linear regression models were used to assess the associations between the variables of interest and ACE2 expression. We initially examined demographic variables alone (bivariate associations and then a multi variable model), then the clinical characteristics (presence of asthma and COPD) for which the sample was enriched, we also assessed models that included cardiovascular disease, hypertension and diabetes, as simple bivariate regression models as well as a model including demographic variables. Due to the relatively low sample size, rather than fitting a full multivariable model and risk over fitting, we used a Random Forrest to identify the important variables from the collective set. Non-parametric bootstrapping was used to asses reliability of the results by fitting the model on each of 50 different samples taken with replacement from the original sample. Regression analyses were performed using R version 4.0.0 (R Core Team (2020).

\section{Results}

We assessed gene expression in primary bronchial epithelial cells (pBECs) from participants of the Newcastle cohort (Table 1), details provided by disease group are summarised separately (Table 2).

\section{Gene expression of $\mathrm{ACE} 2$ and related genes}

Expression of the following genes were assessed. ACE2, the human receptor that SARS-

CoV-2 is known to bind, transmembrane serine protease (TMPRSS)2, cathepsin-L (CTL) and furin, proteases known to be crucial in cleaving the SARS-CoV-2 spike protein and facilitating viral entry $(3-5,20)$. In addition, we examined expression of genes that may be 
medRxiv preprint doi: https://doi.org/10.1101/2020.07.26.20162248; this version posted July 29, 2020. The copyright holder for this preprint

(which was not certified by peer review) is the author/funder, who has granted medRxiv a license to display the preprint in perpetuity.

involved in facilitating SARS-CoV-2 entry. TMPRSS11A/D that also may be involved in spike protein cleavage (21). A disintegrin and metallopeptidase (ADAM)10 and ADAM17, that mediate shedding of ACE2 from the cell surface and promote uptake of SARS-CoV (22, 23). Phosphatidylinositol 4-kinase beta (PI4KB) that creates a lipid microenvironment at the cell surface required for the entry of SARS-CoV-1 as well as other RNA viruses (24). We also assessed the gene expression of proposed alternate receptors for the SARS-CoV-2 notably CD147, as a pre-print suggested this could be an alternate receptor for the virus (25). Finally Heat shock protein (HSPA)5 or GRP78, a protein involved in the unfolded protein response that translocates to the cell surface and may act as an alternative binding site for the virus as has been shown to act in this way in middle-eastern respiratory syndrome (MERS) coronavirus infections (26).

We first determined if there were differences in gene expression between subjects that were healthy controls or had a diagnosis of asthma or COPD (Figure 1). All results are compared to controls (the mean difference compared to controls). ACE2 expression was significantly lower in those with asthma (mean difference fold change ddCT with healthy controls, 0.23, $\mathrm{p}=0.01$ ). Furin was also lower in asthma (mean difference 1.1, $\mathrm{p}=0.02$ ) but there were no differences between groups in the expression of TMPRSS 2 or CTSL. There were no differences in TMPRSS11A/D. ADAM10 was higher in COPD (mean difference $0.15, \mathrm{p}=0.02$ ), ADAM17 was higher in asthma (mean difference $0.18, \mathrm{p}=0.02$ ). The groups were not different in CD147 or PI4KB expression. HSPA5 expression was higher in asthma (mean difference $0.3, \mathrm{p}=0.02$ ).

\section{Age and male sex are associated with higher gene expression}

We next sought to determine if there were any relationships between demographic factors and gene expression. Older age was associated with increased ACE2 (Figure 2) though the 
medRxiv preprint doi: https://doi.org/10.1101/2020.07.26.20162248; this version posted July 29, 2020. The copyright holder for this preprint

(which was not certified by peer review) is the author/funder, who has granted medRxiv a license to display the preprint in perpetuity. All rights reserved. No reuse allowed without permission.

correlation was not strong (Pearson's rho=0.2, $\mathrm{p}=0.02$ ). There was no correlation with body mass index (BMI), pack-years smoked or dose of inhaled corticosteroids used with any of the genes assessed (data not shown). There were no differences seen in gene expression when analysed separately by sex, obesity (BMI>30), atopy, history of hypertension, cardiovascular disease or diabetes, use of inhaled or oral corticosteroids, use of ACE inhibitors, ACE2 or proton pump inhibitors (data not shown).We also assessed if there was any relationship between gene expression and bronchial lavage eosinophils and found no correlations (data not shown). In those with asthma we assessed if there was any difference in those who had evidence of elevated type 2 asthma, evidence of atopy or an airway eosinophil count greater than $2.75 \%$ of the total cell count and found there were no differences.

We also investigated samples from the Perth cohort, firstly to see if there was any difference between samples from children and adults, as children appear to experience less clinical disease. There were no differences between ACE2 gene expression between children and adults.

We then compared ACE2 gene expression between the Perth participants, the healthy controls and Newcastle participants with asthma. While there was no difference in any of the healthy participant groups those with asthma had less ACE2 expression (Figure 2).

We then attempted to control for multiple factors using regression. Due to the relatively low sample size, it was not possible to estimate a full multivariable regression model with all variables of interest without risking over-fitting the results. We attempted to use methods more appropriate in these circumstances (Random Forrest and a LASSO regression), however both of these models did not suggest that there was not evidence of sufficient predictive information in the sample. We therefore focussed on the results of simple bivariate regression analyses of each variable, as well as the models adjusting for demographic characteristics. Of the demographic characteristics, age and sex had significant 
medRxiv preprint doi: https://doi.org/10.1101/2020.07.26.20162248; this version posted July 29, 2020. The copyright holder for this preprint

(which was not certified by peer review) is the author/funder, who has granted medRxiv a license to display the preprint in perpetuity.

All rights reserved. No reuse allowed without permission.

associations with ACE2 expression, and collectively the demographics explained $7.5 \%$ of the variation in ACE2 (Table 3). Asthma was also associated with lower ACE2 expression, however this association was not preserved when adjusting for age, sex and smoking.

\section{Expression of ACE2 in the airway epithelium}

We stained endobronchial biopsies from five healthy controls, 5 subjects with asthma and five COPD with representative slides displayed (Figure 4). In comparing slides between healthy controls aged less than 40 years $(n=5)$ and greater than 65 years $(n=5)$, there appeared to be a marked difference in ACE2 expression in the epithelium in older donors (Figure 4A \&B). Comparing healthy controls to asthma, there again appeared to be less ACE2 with asthma (Figure 4 A\&C). In healthy controls and subjects with COPD there was appreciably greater ACE2 observed in the epithelium and subepithelium compared to asthma, however COPD still had more than normal controls(Figure 4 D,E\&F). Most ACE2 expression appeared to be associated with ciliated as well as basal AECs. It was concentrated at the apical end of the AECs, although, moderate nuclear and cytoplasmic staining was also observed.

\section{Discussion}

The COVID-19 pandemic represents a unique and critical challenge for the world and a greater understanding of the mechanisms of disease overall and in different patient groups, is crucial in determining effective therapeutic responses that so far remain elusive. The SARS-CoV-2 viral spike protein adheres to the ACE2 receptor and enters the host cell with the aid of the serine proteases, TMPRSS2, furin and CTSL by endocytosis $(3,5,20)$. We have confirmed that ACE2 receptor gene and protein are present in AECs. We found 
medRxiv preprint doi: https://doi.org/10.1101/2020.07.26.20162248; this version posted July 29, 2020. The copyright holder for this preprint

(which was not certified by peer review) is the author/funder, who has granted medRxiv a license to display the preprint in perpetuity. All rights reserved. No reuse allowed without permission.

expression is present in equal amounts in children and adults. Expression from lower airway cells is greater in older individuals and males. There appeared to be no differences with smoking or BMI. We also determined that ACE2 gene and protein levels were lower in subjects with asthma. This was also associated with reduced furin expression. Interestingly we also found increased ADAM-17 expression in the epithelium from subjects with asthma, demonstrating a potential mechanism through which IL-13-induced airway inflammation may down regulate ACE2 expression.

Viral respiratory tract infections are common triggers of acute asthma(27), and initially there was great concern that people with asthma would be highly susceptible to SARS-CoV-2. This was the case during the last influenza pandemic in 2009 where asthma patients were overrepresented in those hospitalized with infection (28). Early reports from China (7) and Italy (14) though did not suggest that people with asthma were overrepresented in those hospitalized or who had died from SARS-CoV-2. Age, smoking and male sex though were associated with more severe disease (8). More recently the largest cohort review of more than 17,000 hospitalized cases of COVID-19 from the UK has been pre-published demonstrating that older age, being male, and social deprivation were strongly associated with mortality (29). While chronic lung disease, including COPD was associated with mortality, only those with asthma that had required the recent use of oral corticosteroids had increased mortality (29). We found increased ACE2 was associated with older age and male sex in two independent cohorts in keeping with the epidemiological studies. This suggests that increased lower airway ACE2 expression may be associated with increased risk of more severe disease, and this is consistent with increased ACE2 expression in the small airway epithelium from current smoker and those with COPD $(11,30)$. Asthma alone is not overrepresented in people with COVID-19 nor is it associated with greater disease severity. 
medRxiv preprint doi: https://doi.org/10.1101/2020.07.26.20162248; this version posted July 29, 2020. The copyright holder for this preprint

(which was not certified by peer review) is the author/funder, who has granted medRxiv a license to display the preprint in perpetuity.

This raises the question as to why people with asthma are not at increased susceptibility to SARS-CoV-2.

SARS-CoV-2 is a highly infectious virus transmitted by airway droplets (31). Cell entry is the first step necessary and cell tropism is key to infectivity. SARS-CoV-2 uses the ACE2 receptor as its point of entry and this receptor has been found to be highly expressed in the upper airway $(32,33)$. Unlike other coronaviruses (OC43, 229E and NL63) that cause mild upper respiratory tract infections, SARS-CoV and SARS-CoV-2 are able to spread to the lower respiratory tract resulting in pneumonia (34). While ACE2 is expressed in the lower respiratory tract, in keeping with our results, there is relatively lower levels of expression compared to the upper regions. SARS-CoV-2 is able to infect firstly ciliated columnar epithelial cells and then appears to spread to surrounding secretory cells (35). ACE2 expression is critical for lower airway infection to occur, and mice deficient in the receptor had greatly reduced SARS-CoV infection and replication (36). Thus, it is likely that the level of ACE2 expression in lower airway cells may be an important factor in determining more severe infection with SARS-CoV-2.

Higher pre-infection levels of ACE2 may lead to an increased risk of infection with SARS-CoV-2. This was proposed by Leung et al., where they demonstrated increased ACE2 expression from resected lung tissue and endobronchial brushings from 26 subjects who were current or former smokers as well as subjects with COPD (30). This phenomenon is seen with the relationship between infection and influenza strains between species where tropism for sialic acid residues determines the ability of influenza strains to be transmitted between species (37).

The entry of SARS-CoV and SARS-CoV-2 into cells is facilitated by the interaction between viral S-protein with the extracellular domain of the transmembrane ACE2 protein. Endocytosis of the virus then results in downregulation of surface ACE2 expression $(3,38$, 
medRxiv preprint doi: https://doi.org/10.1101/2020.07.26.20162248; this version posted July 29,2020 . The copyright holder for this preprint

(which was not certified by peer review) is the author/funder, who has granted medRxiv a license to display the preprint in perpetuity.

39). Once infection is established SARS-CoV has been shown to upregulate ADAM-17 that facilitates further viral endocytosis with ACE2, while knockdown of ADAM-17 by siRNA prior to infection substantially attenuates SARS-CoV entry (40). In 12 selected patients with COVID-19 and the 6 of these who developed ARDS, circulating angiotensin II levels were markedly elevated, which correlated with viral load as measured by PCR and the degree of pathology. This suggests a link in SARS-CoV-2 infection with tissue ACE2 downregulation facilitating the development of ARDS (41). The spread of infection to the lower airways is reflected in the clinical presentation of the illness, with the first 4-5 days often asymptomatic, followed by dry cough and fever, with viral load peaking at day 10, with those who go onto to develop severe disease, ARDS and severe systemic immune responses 7-10 days after infection $(7,42)$.

The biologic importance of reduced ACE2 gene expression and protein levels that we find in asthma is also supported by the observation of reduced expression of furin, a protease that together with TMPRSS 2 has been found to be critical in facilitating SARS-COV-2 endocytosis (20). We also found enhanced expression of ADAM-17. Phosphorylation of ACE2 enhances its catalytic activity and increases its shedding from the epithelial surface (43). The role of ADAM-17 is not well defined in asthma but its presence in airway epithelial cells has been proposed to be anti-inflammatory and linked to increased airway remodelling and goblet cell hyperplasia (44). Enhanced ADAM-17 activity is a potential mechanism by which ACE2 receptor expression could be downregulated specifically in asthma.

Two other studies have examined reduced ACE2 mRNA expression in epithelial cells from people with asthma. Similar to us Jackson et al., showed reduced ACE2 expression in nasal samples from children and adults and bronchial epithelial cells from 10 steroid naïve allergic asthma patients (45). They demonstrated a negative correlation of ACE2 expression with type 2 airway inflammation, exhaled nitric oxide and nasal epithelial IL-13 expression. 
medRxiv preprint doi: https://doi.org/10.1101/2020.07.26.20162248; this version posted July 29, 2020. The copyright holder for this preprint

(which was not certified by peer review) is the author/funder, who has granted medRxiv a license to display the preprint in perpetuity.

In contrast Bradding et al examined bronchial brushings and endobronchial biopsies and looked for expression of ACE2, TMPRSS2 and Furin(46). Results were available from 356 patients ( 88 healthy volunteers and 268 patients with asthma (mild to severe). They did not see any difference between participants with asthma or healthy controls but did find weak though statistically significant positive correlations between a TH-17 gene signature and negative correlation with a TH-2 gene signature. We saw reduced ACE2 expression in asthma, we not find a difference in ACE2 expression with atopy alone, nor did we see a significant relationship between ACE2 and bronchial lavage eosinophil count. Our cells had been cultured after harvest without stimulation. There is now evidence that treatment of AEC cultures with IL-13 reduces the expression of ACE2 (47). Interestingly it has been shown that IL-13 induced epithelial proliferation is mediated by ADAM-17 (48). This could provide a unifying mechanism by which the effect of IL-13 on tissue remodelling of the airway epithelium as occurs in severe allergic disease and asthma may lead to down regulation of ACE2 expression in the lower airways.

In contrast to our results increased expression of ACE2 and TMPRSS2 was found in over 300 induced sputum samples from a cohort with severe asthma, though the use of inhaled steroids was associated with lower ACE2 expression (49). These results however are from induced sputum and the RNA content will have largely come from immune cells and not the airway epithelium. Interferons have also been shown to influence ACE2 expression, and it is possible that a deficient interferon response in asthma, may be associated with reduced airway expression of ACE2(50). Another alternate possibility is that inhaled corticosteroids (ICS) may reduce ACE2 expression. All our participants with asthma were on ICS and the majority were taking moderate to high doses. We did not see a negative correlation between ICS dose and ACE2 expression and subjects on ICS independent of asthma did not have lower ACE2 expression. The effect of ICS on antiviral immunity is 
medRxiv preprint doi: https://doi.org/10.1101/2020.07.26.20162248; this version posted July 29,2020 . The copyright holder for this preprint

(which was not certified by peer review) is the author/funder, who has granted medRxiv a license to display the preprint in perpetuity.

unclear and there is as yet no data to determine if the risk with COVID-19 is increased or decreased (51).

Our study has some weaknesses. We examined specimens of AECs from a relatively large cohort, who were recruited to study chronic airways disease and were enriched for subjects with moderate to severe asthma and COPD. Our numbers overall and with asthma though were not large enough to give a clear answer with multivariate analysis to define if this was independent of age and sex, and it is likely we would need to have included younger people with asthma. All of our subjects were on ICS and had required either GINA step 3 or above treatment. The majority, 28/39(72\%) had evidence of type 2 high airway inflammation, with either atopy or elevated airway eosinophils. We had relatively few participants with other diseases, such as hypertension, diabetes and cardiovascular disease and relatively few on ACE inhibitors, meaning we cannot make any reliable predictions about these groups. Similarly, we had relatively few current smokers, though a larger number of former smokers, and the effect may have been confounded by the fact that all these smokers had been selected because of chronic airways disease. ACE2 expression and associated proteases are but one factor that will be associated with susceptibility to infection. Similarly, the risk of severe disease or the development of complications from COVID-19 will be more complex than receptor expression alone for the virus.

We present the largest pathology study that looks at ACE2 expression from lower airway bronchial epithelial cells enriched with people with asthma and COPD. We have confirmed the presence of ACE2 in samples from children and adults in two independent cohorts and determined with bivariate analysis that age and male sex is associated with increased lower airway ACE2 expression. Our data provides further evidence for the differences observed in RNA expression confirming reduced ACE2 protein levels in subjects with asthma by immunohistochemistry. We are now the second group to find that people with 
medRxiv preprint doi: https://doi.org/10.1101/2020.07.26.20162248; this version posted July 29, 2020. The copyright holder for this preprint

(which was not certified by peer review) is the author/funder, who has granted medRxiv a license to display the preprint in perpetuity.

All rights reserved. No reuse allowed without permission.

asthma have reduced ACE2 expression in lower airway cells. We propose that this may provide a degree of protection from the complications of SARS-CoV-2. The next step is to determine from current epidemiological studies of COVID transmission what is the risk of infection in asthma and whether these people are relatively protected. We find reduced ACE2 expression associated with reduced furin expression in asthma and observe increased expression of ADAM-17. This provides a potential mechanism by which chronic airway inflammation associated with asthma and the action of IL-13 on the airway epithelium could down regulate ACE2 expression via ADAM17 prior to infection. Further studies should now be done to define this mechanism and determine whether this can be manipulated as a therapeutic target to reduce SARS-CoV-2 infection of the airway epithelium.

\section{Acknowledgements:}

Sohal SS is supported by Clifford Craig Foundation Launceston General Hospital, Rebecca

L. Cooper Medical Research Foundation.

PMH is supportedfunded by Clifford Craig Foundation Launceston General Hospital,

Rebecca L. Coopera Fellowship and grants from the National Health and Medical Research Foundation.Council (NHMRC) of Australia (1079187, 1175134) and SPHERE.

\section{Legends}

\section{Figure 1}

All values are represented individually. The mean and standard deviation is also presented. Differences between the groups were assessed using one-way ANOVA, with Dunnett's multiple comparison test. If the ANOVA was significant $(\mathrm{p}<0.05)$, the $\mathrm{p}$ values are labelled for the group that is different from the healthy controls.

Figure 2 
medRxiv preprint doi: https://doi.org/10.1101/2020.07.26.20162248; this version posted July 29,2020 . The copyright holder for this preprint

(which was not certified by peer review) is the author/funder, who has granted medRxiv a license to display the preprint in perpetuity.

All rights reserved. No reuse allowed without permission.

Panel A represents data from the Newcastle cohort $(n=116)$ a two-way comparison between ACE2 expression and age. The univariate correlation was measured using Pearson's correlation co-efficient with a two-sided test for significance.

Panel B, represents the same data with subjects divided by age group. The mean and standard deviation are represented. Differences between the two groups was analysed using an unpaired t-test.

\section{Figure 3}

Data represents ACE2 gene expression seen in AECs from Perth adults $(n=16)$, Perth children $(n=14)$, Newcastle adult healthy controls $(n=40)$, Newcastle asthma $(n=37)$. Differences between the groups were assessed using one-way ANOVA, with Dunnett's multiple comparison test.

\section{Figure 4}

Panels A-C representative immunofluorescent images of formalin-fixed paraffin-embedded endo-bronchial sections showing protein expression of CADHERIN1 (green) and ACE2 (red) in healthy controls (A)under 40 years compared to (B) a healthy control over 40 years. C healthy control (aged 42) and (D) asthma (aged 49).

Panel D,E,F: are representative images of endobronchial biopsies stained for ACE2. The images (D) shows healthy controls compared to (E) asthma and (F) COPD. Magnification $\mathrm{X} 40$. 
medRxiv preprint doi: https://doi.org/10.1101/2020.07.26.20162248; this version posted July 29, 2020. The copyright holder for this preprint (which was not certified by peer review) is the author/funder, who has granted medRxiv a license to display the preprint in perpetuity. All rights reserved. No reuse allowed without permission.

\section{References}

1. Zhou P, Yang XL, Wang XG, Hu B, Zhang L, Zhang W, Si HR, Zhu Y, Li B, Huang CL, Chen HD, Chen J, Luo Y, Guo H, Jiang RD, Liu MQ, Chen Y, Shen XR, Wang X, Zheng XS, Zhao K, Chen QJ, Deng F, Liu LL, Yan B, Zhan FX, Wang YY, Xiao GF, Shi ZL. A pneumonia outbreak associated with a new coronavirus of probable bat origin. Nature 2020; 579: 270-273.

2. Zhu N, Zhang D, Wang W, Li X, Yang B, Song J, Zhao X, Huang B, Shi W, Lu R, Niu P, Zhan F, Ma X, Wang D, Xu W, Wu G, Gao GF, Tan W. A Novel Coronavirus from Patients with Pneumonia in China, 2019. New England Journal of Medicine 2020; 382: 727-733.

3. Hoffmann M, Kleine-Weber $H$, Schroeder S, Krüger N, Herrler T, Erichsen S, Schiergens TS, Herrler G, Wu NH, Nitsche A, Müller MA, Drosten C, Pöhlmann S. SARS-CoV-2 Cell Entry Depends on ACE2 and TMPRSS2 and Is Blocked by a Clinically Proven Protease Inhibitor. Cell 2020.

4. Ou X, Liu Y, Lei X, Li P, Mi D, Ren L, Guo L, Guo R, Chen T, Hu J, Xiang Z, Mu Z, Chen X, Chen J, Hu K, Jin $Q$, Wang J, Qian Z. Characterization of spike glycoprotein of SARS-CoV-2 on virus entry and its immune cross-reactivity with SARS-CoV. Nature Communications 2020; 11: 1620.

5. Shang J, Wan Y, Luo C, Ye G, Geng Q, Auerbach A, Li F. Cell entry mechanisms of SARS-CoV-2. Proceedings of the National Academy of Sciences 2020: 202003138.

6. Dong E, Du H, Gardner L. An interactive web-based dashboard to track COVID-19 in real time. The Lancet Infectious Diseases 2020; 20: 533-534.

7. Zhou F, Yu T, Du R, Fan G, Liu Y, Liu Z, Xiang J, Wang Y, Song B, Gu X, Guan L, Wei Y, Li H, Wu X, Xu J, Tu S, Zhang Y, Chen H, Cao B. Clinical course and risk factors for mortality of adult inpatients with COVID-19 in Wuhan, China: a retrospective cohort study. Lancet 2020.

8. Rodriguez-Morales AJ, Cardona-Ospina JA, Gutiérrez-Ocampo E, Villamizar-Peña R, Holguin-Rivera $Y$, Escalera-Antezana JP, Alvarado-Arnez LE, Bonilla-Aldana DK, Franco-Paredes C, HenaoMartinez AF, Paniz-Mondolfi A, Lagos-Grisales GJ, Ramírez-Vallejo E, Suárez JA, Zambrano LI, Villamil-Gómez WE, Balbin-Ramon GJ, Rabaan AA, Harapan H, Dhama K, Nishiura H, Kataoka $\mathrm{H}$, Ahmad T, Sah R. Clinical, laboratory and imaging features of COVID-19: A systematic review and meta-analysis. Travel Med Infect Dis 2020: 101623.

9. Loubet $P$, Samih-Lenzi N, Galtier F, Vanhems $P$, Loulergue $P$, Duval X, Jouneau S, Postil D, Rogez $S$, Valette M, Merle C, Régis C, Costa Y, Lesieur Z, Tattevin P, Lina B, Carrat F, Launay O. Factors associated with poor outcomes among adults hospitalized for influenza in France: $A$ threeyear prospective multicenter study. J Clin Virol 2016; 79: 68-73.

10. Guan WJ, Liang WH, Zhao Y, Liang HR, Chen ZS, Li YM, Liu XQ, Chen RC, Tang CL, Wang T, Ou CQ, Li L, Chen PY, Sang L, Wang W, Li JF, Li CC, Ou LM, Cheng B, Xiong S, Ni ZY, Xiang J, Hu Y, Liu L, Shan H, Lei CL, Peng YX, Wei L, Liu Y, Hu YH, Peng P, Wang JM, Liu JY, Chen Z, Li G, Zheng ZJ, Qiu SQ, Luo J, Ye CJ, Zhu SY, Cheng LL, Ye F, Li SY, Zheng JP, Zhang NF, Zhong NS, He JX. Comorbidity and its impact on 1590 patients with Covid-19 in China: A Nationwide Analysis. Eur Respir J 2020.

11. Brake SJ, Barnsley K, Lu W, McAlinden KD, Eapen MS, Sohal SS. Smoking Upregulates Angiotensin-Converting Enzyme-2 Receptor: A Potential Adhesion Site for Novel Coronavirus SARS-CoV-2 (Covid-19). J Clin Med 2020; 9.

12. Du R-H, Liang L-R, Yang C-Q, Wang W, Cao T-Z, Li M, Guo G-Y, Du J, Zheng C-L, Zhu Q, Hu M, Li X$\mathrm{Y}$, Peng P, Shi H-Z. Predictors of Mortality for Patients with COVID-19 Pneumonia Caused by SARS-CoV-2: A Prospective Cohort Study. European Respiratory Journal 2020: 2000524.

13. Shi Y, Yu X, Zhao H, Wang H, Zhao R, Sheng J. Host susceptibility to severe COVID-19 and establishment of a host risk score: findings of 487 cases outside Wuhan. Crit Care 2020; 24: 108.

14. Grasselli G, Zangrillo A, Zanella A, Antonelli M, Cabrini L, Castelli A, Cereda D, Coluccello A, Foti G, Fumagalli R, lotti G, Latronico N, Lorini L, Merler S, Natalini G, Piatti A, Ranieri MV, 
medRxiv preprint doi: https://doi.org/10.1101/2020.07.26.20162248; this version posted July 29, 2020. The copyright holder for this preprint (which was not certified by peer review) is the author/funder, who has granted medRxiv a license to display the preprint in perpetuity. All rights reserved. No reuse allowed without permission.

Scandroglio AM, Storti E, Cecconi M, Pesenti A. Baseline Characteristics and Outcomes of 1591 Patients Infected With SARS-CoV-2 Admitted to ICUs of the Lombardy Region, Italy. JAMA 2020.

15. Lokwani R, Wark PAB, Baines KJ, Barker D, Simpson JL. Hypersegmented airway neutrophils and its association with reduced lung function in adults with obstructive airway disease: an exploratory study. BMJ Open 2019; 9: e024330-e024330.

16. Singanayagam A, Loo SL, Calderazzo M, Finney LJ, Trujillo Torralbo MB, Bakhsoliani E, Girkin J, Veerati P, Pathinayake PS, Nichol KS, Reid A, Footitt J, Wark PAB, Grainge CL, Johnston SL, Bartlett NW, Mallia P. Antiviral immunity is impaired in COPD patients with frequent exacerbations. Am J Physiol Lung Cell Mol Physiol 2019; 317: L893-I903.

17. Kicic A, Sutanto EN, Stevens PT, Knight DA, Stick SM. Intrinsic biochemical and functional differences in bronchial epithelial cells of children with asthma. Am J Respir Crit Care Med 2006; 174: 1110-1118.

18. Martinovich KM, losifidis T, Buckley AG, Looi K, Ling KM, Sutanto EN, Kicic-Starcevich E, Garratt LW, Shaw NC, Montgomery S, Lannigan FJ, Knight DA, Kicic A, Stick SM. Conditionally reprogrammed primary airway epithelial cells maintain morphology, lineage and disease specific functional characteristics. Sci Rep 2017; 7: 17971.

19. Rao X, Huang X, Zhou Z, Lin X. An improvement of the $2^{\wedge}$ (-delta delta CT) method for quantitative real-time polymerase chain reaction data analysis. Biostatistics, bioinformatics and biomathematics 2013; 3: 71-85.

20. Bestle D, Heindl MR, Limburg H, van TVL, Pilgram O, Moulton H, Stein DA, Hardes K, Eickmann M, Dolnik O, Rohde C, Becker S, Klenk H-D, Garten W, Steinmetzer T, Böttcher-Friebertshäuser E. TMPRSS2 and furin are both essential for proteolytic activation and spread of SARS-CoV-2 in human airway epithelial cells and provide promising drug targets. bioRxiv 2020: 2020.2004.2015.042085.

21. Bertram S, Glowacka I, Müller MA, Lavender H, Gnirss K, Nehlmeier I, Niemeyer D, He Y, Simmons G, Drosten C, Soilleux EJ, Jahn O, Steffen I, Pöhlmann S. Cleavage and activation of the severe acute respiratory syndrome coronavirus spike protein by human airway trypsinlike protease. J Virol 2011; 85: 13363-13372.

22. Jia HP, Look DC, Tan P, Shi L, Hickey M, Gakhar L, Chappell MC, Wohlford-Lenane C, McCray PB, Jr. Ectodomain shedding of angiotensin converting enzyme 2 in human airway epithelia. $A m$ J Physiol Lung Cell Mol Physiol 2009; 297: L84-96.

23. Haga S, Nagata N, Okamura T, Yamamoto N, Sata T, Yamamoto N, Sasazuki T, Ishizaka Y. TACE antagonists blocking ACE2 shedding caused by the spike protein of SARS-CoV are candidate antiviral compounds. Antiviral Res 2010; 85: 551-555.

24. Yang N, Ma P, Lang J, Zhang Y, Deng J, Ju X, Zhang G, Jiang C. Phosphatidylinositol 4-Kinase III $\beta$ Is Required for Severe Acute Respiratory Syndrome Coronavirus Spike-mediated Cell Entry. Journal of Biological Chemistry 2012; 287: 8457-8467.

25. Wang K, Chen W, Zhou Y-S, Lian J-Q, Zhang Z, Du P, Gong L, Zhang Y, Cui H-Y, Geng J-J, Wang B, Sun $X-X$, Wang $C-F$, Yang $X$, Lin $P$, Deng $Y-Q$, Wei D, Yang $X-M$, Zhu $Y-M$, Zhang K, Zheng Z-H, Miao J-L, Guo T, Shi Y, Zhang J, Fu L, Wang Q-Y, Bian H, Zhu P, Chen Z-N. SARS-CoV-2 invades host cells via a novel route: CD147-spike protein. bioRxiv 2020: 2020.2003.2014.988345.

26. Chu H, Chan C-M, Zhang X, Wang Y, Yuan S, Zhou J, Au-Yeung RK-H, Sze K-H, Yang D, Shuai H, Hou Y, Li C, Zhao X, Poon VK-M, Leung SP, Yeung M-L, Yan J, Lu G, Jin D-Y, Gao GF, Chan JF-W, Yuen K-Y. Middle East respiratory syndrome coronavirus and bat coronavirus HKU9 both can utilize GRP78 for attachment onto host cells. J Biol Chem 2018; 293: 11709-11726.

27. Hansbro NG, Horvat JC, Wark PA, Hansbro PM. Understanding the mechanisms of viral induced asthma: new therapeutic directions. Pharmacol Ther 2008; 117: 313-353.

28. Jha A, Dunning J, Tunstall T, Thwaites RS, Hoang LT, Kon OM, Zambon MC, Hansel TT, Openshaw PJ. Patterns of systemic and local inflammation in patients with asthma hospitalised with influenza. European Respiratory Journal 2019: 1900949. 
medRxiv preprint doi: https://doi.org/10.1101/2020.07.26.20162248; this version posted July 29, 2020. The copyright holder for this preprint

(which was not certified by peer review) is the author/funder, who has granted medRxiv a license to display the preprint in perpetuity. All rights reserved. No reuse allowed without permission.

29. Williamson E, Walker AJ, Bhaskaran KJ, Bacon S, Bates C, Morton CE, Curtis HJ, Mehrkar A, Evans D, Inglesby P, Cockburn J, Mcdonald HI, MacKenna B, Tomlinson L, Douglas IJ, Rentsch CT, Mathur R, Wong A, Grieve R, Harrison D, Forbes H, Schultze A, Croker RT, Parry J, Hester F, Harper S, Perera R, Evans S, Smeeth L, Goldacre B. OpenSAFELY: factors associated with COVID-19-related hospital death in the linked electronic health records of 17 million adult NHS patients. medRxiv 2020: 2020.2005.2006.20092999.

30. Leung JM, Yang CX, Tam A, Shaipanich T, Hackett TL, Singhera GK, Dorscheid DR, Sin DD. ACE-2 Expression in the Small Airway Epithelia of Smokers and COPD Patients: Implications for COVID-19. medRxiv 2020: 2020.2003.2018.20038455.

31. Sanche S, Lin YT, Xu C, Romero-Severson E, Hengartner N, R. K. High contagiousness and rapid spread of severe acute respiratory syndrome coronavirus 2. Emerg Infect Dis 2020.

32. Sungnak W, Huang N, Bécavin C, Berg M, Queen R, Litvinukova M, Talavera-López C, Maatz H, Reichart D, Sampaziotis F, Worlock KB, Yoshida M, Barnes JL, Banovich NE, Barbry P, Brazma A, Collin J, Desai TJ, Duong TE, Eickelberg O, Falk C, Farzan M, Glass I, Gupta RK, Haniffa M, Horvath $P$, Hubner N, Hung D, Kaminski N, Krasnow M, Kropski JA, Kuhnemund M, Lako M, Lee H, Leroy S, Linnarson S, Lundeberg J, Meyer KB, Miao Z, Misharin AV, Nawijn MC, Nikolic MZ, Noseda M, Ordovas-Montanes J, Oudit GY, Pe'er D, Powell J, Quake S, Rajagopal J, Tata PR, Rawlins EL, Regev A, Reyfman PA, Rozenblatt-Rosen O, Saeb-Parsy K, Samakovlis C, Schiller HB, Schultze JL, Seibold MA, Seidman CE, Seidman JG, Shalek AK, Shepherd D, Spence J, Spira A, Sun X, Teichmann SA, Theis FJ, Tsankov AM, Vallier L, van den Berge M, Whitsett J, Xavier R, Xu Y, Zaragosi L-E, Zerti D, Zhang H, Zhang K, Rojas M, Figueiredo F, Network HCALB. SARS-CoV-2 entry factors are highly expressed in nasal epithelial cells together with innate immune genes. Nature Medicine 2020; 26: 681-687.

33. Xu H, Zhong L, Deng J, Peng J, Dan H, Zeng X, Li T, Chen Q. High expression of ACE2 receptor of 2019-nCoV on the epithelial cells of oral mucosa. International Journal of Oral Science 2020; 12: 8.

34. Tay MZ, Poh CM, Renia L, MacAry PA, Ng LFP. The trinity of COVID-19: immunity, inflammation and intervention. Nat Rev Immunol 2020.

35. Ravindra NG, Alfajaro MM, Gasque V, Wei J, Filler RB, Huston NC, Wan H, Szigeti-Buck K, Wang B, Montgomery RR, Eisenbarth SC, Williams A, Pyle AM, Iwasaki A, Horvath TL, Foxman EF, van Dijk D, Wilen CB. Single-cell longitudinal analysis of SARS-CoV-2 infection in human bronchial epithelial cells. bioRxiv 2020: 2020.2005.2006.081695.

36. Kuba K, Imai Y, Rao S, Gao H, Guo F, Guan B, Huan Y, Yang P, Zhang Y, Deng W, Bao L, Zhang B, Liu G, Wang Z, Chappell M, Liu Y, Zheng D, Leibbrandt A, Wada T, Slutsky AS, Liu D, Qin C, Jiang $C$, Penninger JM. A crucial role of angiotensin converting enzyme 2 (ACE2) in SARS coronavirus-induced lung injury. Nat Med 2005; 11: 875-879.

37. Suzuki Y, Ito T, Suzuki T, Holland RE, Jr., Chambers TM, Kiso M, Ishida H, Kawaoka Y. Sialic acid species as a determinant of the host range of influenza A viruses. J Virol 2000; 74: 1182511831.

38. Li W, Moore MJ, Vasilieva N, Sui J, Wong SK, Berne MA, Somasundaran M, Sullivan JL, Luzuriaga $\mathrm{K}$, Greenough TC, Choe H, Farzan M. Angiotensin-converting enzyme 2 is a functional receptor for the SARS coronavirus. Nature 2003; 426: 450-454.

39. Dijkman R, Jebbink MF, Deijs M, Milewska A, Pyrc K, Buelow E, van der Bijl A, van der Hoek L. Replication-dependent downregulation of cellular angiotensin-converting enzyme 2 protein expression by human coronavirus NL63. J Gen Virol 2012; 93: 1924-1929.

40. Haga S, Yamamoto N, Nakai-Murakami C, Osawa Y, Tokunaga K, Sata T, Yamamoto N, Sasazuki T, Ishizaka Y. Modulation of TNF-alpha-converting enzyme by the spike protein of SARS-CoV and ACE2 induces TNF-alpha production and facilitates viral entry. Proc Natl Acad Sci U S A 2008; 105: 7809-7814.

41. Liu Y, Yang Y, Zhang C, Huang F, Wang F, Yuan J, Wang Z, Li J, Li J, Feng C, Zhang Z, Wang L, Peng L, Chen L, Qin Y, Zhao D, Tan S, Yin L, XU J, Zhou C, Jiang C, Liu L. Clinical and biochemical 
medRxiv preprint doi: https://doi.org/10.1101/2020.07.26.20162248; this version posted July 29, 2020 . The copyright holder for this preprint

(which was not certified by peer review) is the author/funder, who has granted medRxiv a license to display the preprint in perpetuity. All rights reserved. No reuse allowed without permission.

indexes from 2019-nCoV infected patients linked to viral loads and lung injury. Sci China Life Sci 2020; 63: 364-374.

42. Zou L, Ruan F, Huang M, Liang L, Huang H, Hong Z, Yu J, Kang M, Song Y, Xia J, Guo Q, Song T, He J, Yen HL, Peiris M, Wu J. SARS-CoV-2 Viral Load in Upper Respiratory Specimens of Infected Patients. N Engl J Med 2020; 382: 1177-1179.

43. Patel VB, Clarke N, Wang Z, Fan D, Parajuli N, Basu R, Putko B, Kassiri Z, Turner AJ, Oudit GY. Angiotensin II induced proteolytic cleavage of myocardial ACE2 is mediated by TACE/ADAM17: a positive feedback mechanism in the RAS. J Mol Cell Cardiol 2014; 66: 167-176.

44. Dreymueller D, Uhlig S, Ludwig A. ADAM-family metalloproteinases in lung inflammation: potential therapeutic targets. Am J Physiol Lung Cell Mol Physiol 2015; 308: L325-343.

45. Jackson DJ, Busse WW, Bacharier LB, Kattan M, O'Connor GT, Wood RA, Visness CM, Durham SR, Larson D, Esnault S, Ober C, Gergen PJ, Becker P, Togias A, Gern JE, Altman MC. Association of respiratory allergy, asthma, and expression of the SARS-CoV-2 receptor ACE2. J Allergy Clin Immunol 2020.

46. Bradding P, Richardson M, Hinks TSC, Howarth PH, Choy DF, Arron JR, Wenzel SE, Siddiqui S. ACE2, TMPRSS2, and furin gene expression in the airways of people with asthmaimplications for COVID-19. The Journal of allergy and clinical immunology 2020; 146: 208211.

47. Kimura H, Francisco D, Conway M, Martinez FD, Vercelli D, Polverino F, Billheimer D, Kraft M. Type 2 Inflammation Modulates ACE2 and TMPRSS2 in Airway Epithelial Cells. Journal of Allergy and Clinical Immunology 2020.

48. Booth BW, Sandifer T, Martin EL, Martin LD. IL-13-induced proliferation of airway epithelial cells: mediation by intracellular growth factor mobilization and ADAM17. Respir Res 2007; 8: 51.

49. Peters MC, Sajuthi S, Deford P, Christenson S, Rios CL, Montgomery MT, Woodruff PG, Mauger DT, Erzurum SC, Johansson MW, Denlinger LC, Jarjour NN, Castro M, Hastie AT, Moore W, Ortega VE, Bleecker ER, Wenzel SE, Israel E, Levy BD, Seibold MA, Fahy JV. COVID-19 Related Genes in Sputum Cells in Asthma: Relationship to Demographic Features and Corticosteroids. Am J Respir Crit Care Med 2020.

50. Fitzgerald KA. 2000.

51. Halpin DMG, Singh D, Hadfield RM. Inhaled corticosteroids and COVID-19: a systematic review and clinical perspective. European Respiratory Journal 2020: 2001009.

52. Hsu AC, Dua K, Starkey MR, Haw TJ, Nair PM, Nichol K, Zammit N, Grey ST, Baines KJ, Foster PS, Hansbro PM, Wark PA. MicroRNA-125a and -b inhibit A20 and MAVS to promote inflammation and impair antiviral response in COPD. JCl Insight 2017; 2: e90443. 
medRxiv preprint doi: https://doi.org/10.1101/2020.07.26.20162248; this version posted July 29,2020 . The copyright holder for this preprint (which was not certified by peer review) is the author/funder, who has granted medRxiv a license to display the preprint in perpetuity.

Table 1 Participants

\begin{tabular}{|c|c|}
\hline Number & 116 \\
\hline Age & $62(13.5)$ \\
\hline Sex & Male $49(42 \%)$ Female $67(58 \%)$ \\
\hline Smoking status & $\begin{array}{l}\text { Never } 48(41 \%), \text { Ex-smoker } 59(51 \%), \text { Current } 9 \\
(8 \%)\end{array}$ \\
\hline BMI & $29.6(6.6)$ \\
\hline Asthma & $39(33.6 \%)$ \\
\hline COPD & $38(33 \%)$ \\
\hline Atopy & $23 / 92(33 \%)^{*}$ \\
\hline Cardiovascular disease & $8(7 \%)$ \\
\hline Hypertension & $22(19 \%)$ \\
\hline Diabetes & $12(10 \%)$ \\
\hline Malignancy & $9(8 \%)$ \\
\hline Gastroesophageal reflux & $55(47 \%)$ \\
\hline $\begin{array}{l}\text { Prescribed regular } \\
\text { Inhaled corticosteroids }\end{array}$ & $55(47 \%)$ \\
\hline $\begin{array}{l}\text { Prescribed regular oral } \\
\text { corticosteroids }\end{array}$ & $5(4 \%)$ \\
\hline $\begin{array}{l}\text { Prescribed regular ACE } \\
\text { or ARB inhibitor }\end{array}$ & $12(10 \%)$ \\
\hline $\begin{array}{l}\text { Prescribed regular proton } \\
\text { pump inhibitor }\end{array}$ & $23(20 \%)$ \\
\hline
\end{tabular}

\section{Legend Table 1}

* 14 had no documented allergy by either skin prick test or radioimmunosorbent assay BMI, body mass index. COPD, chronic obstructive pulmonary disease.ACE, angiotensin converting enzyme. ARB, angiotensin II receptor blocker. 
medRxiv preprint doi: https://doi.org/10.1101/2020.07.26.20162248; this version posted July 29, 2020. The copyright holder for this preprint (which was not certified by peer review) is the author/funder, who has granted medRxiv a license to display the preprint in perpetuity. All rights reserved. No reuse allowed without permission.

Table 2 Clinical details by disease groups in the Newcastle cohort.

\begin{tabular}{|l|c|c|c|c|}
\hline & Healthy & Asthma & COPD & Analysis \\
\hline Number & 39 & 39 & 38 & $\mathrm{NA}$ \\
\hline $\begin{array}{l}\text { Age years (mean \& } \\
\text { SD) }\end{array}$ & $64(55.1,71.5)$ & $53.2(14.8)$ & $68.2(8.2)$ & $\mathrm{p}=08$ \\
\hline Sex, male:female & $11: 28$ & $16: 23$ & $16: 22$ & $\mathrm{p}=0.7$ \\
\hline $\begin{array}{l}\text { Packet years smoked } \\
\text { (Mean \& SD) }\end{array}$ & 0 & 0 & $38.6(34.9)$ & $\mathrm{p}<0.001$ \\
\hline $\begin{array}{l}\text { FEV1pp (Median \& } \\
\text { interquartile range) }\end{array}$ & $90(83.5$, & $64.5(49.8,86.3)$ & $46.5(40,64)$ & $\mathrm{p}<0.001^{*}$ \\
\hline $\begin{array}{l}\text { Regular ICS } \\
\text { (\%) }\end{array}$ & $130.1)$ & $39(100 \%)$ & $17(42 \%)$ & $\mathrm{p}=0.001$ \\
\hline $\begin{array}{l}\text { ICS, median BDP/d, } \\
\text { (Median \& } \\
\text { interquartile range) }\end{array}$ & 0 & $1600(800$, & $1600(800$, & $\mathrm{p}=0.8^{* * *}$ \\
\hline Atopy & 0 & $2000)$ & $2000)$ & \\
\hline $\begin{array}{l}\text { Airway eosinophils, } \\
\% \text { total cell count } \\
\text { (median \& } \\
\text { interquartile range) }\end{array}$ & $1.0(0.25,1.6)$ & $19(49 \%)$ & $4(10.1 \%)$ & $\mathrm{p}<0.001$ \\
\hline $\begin{array}{l}\text { GINA } \\
\text { GINA step 3 }\end{array}$ & & & $0.9(0.5,10.1)$ & $\mathrm{p}=0.002^{* * *}$ \\
$\begin{array}{l}\text { GINA step 4 } \\
\text { GINA step 5 }\end{array}$ & & & & \\
\hline TH2 high disease & NA & $28(72 \%)$ & $\mathrm{NA}$ & \\
\hline $\begin{array}{l}\text { GOLD } \\
\text { GOLD 2 }\end{array}$ & & & & \\
$\begin{array}{l}\text { GOLD 3 } \\
\text { GOLD 4 }\end{array}$ & & & & \\
\hline
\end{tabular}

\section{Legend Table 2}

FEV1pp; FEV1 percentage of the predicted value.

Packet years smoked, 1 packet of 25 cigarettes or equivalent per day for 1 year.

ICS dose expressed as equivalent beclomethasone (BDP) in mcg per day. Where $1 \mathrm{mcg}$ of BDP is equivalent to $1 \mathrm{mcg}$ Budesonide, $0.5 \mathrm{mcg}$ Fluticasone propionate and $0.4 \mathrm{mcg}$

Ciclosenide.

$\mathrm{TH} 2$ high disease, was defined as evidence of either atopy or elevated airway eosinophils ( $2.75 \%$ of the total cell count).

* FEV1 was significantly lower in participants with COPD, compared to both healthy controls $(\mathrm{p}<0.001)$ and asthma $(\mathrm{p}=0.01)$. FEV1 was lower in participants with asthma compared to healthy controls $(\mathrm{p}<0.001)$. Kruskal Wallis with Dunn's comparison.

** ICS dose was different between those with asthma and COPD.

*** Participants with asthma had higher airway eosinophils compared to healthy controls.

Kruskal Wallis with Dunn's comparison. 
medRxiv preprint doi: https://doi.org/10.1101/2020.07.26.20162248; this version posted July 29, 2020. The copyright holder for this preprint (which was not certified by peer review) is the author/funder, who has granted medRxiv a license to display the preprint in perpetuity.

Table 3

\begin{tabular}{|c|c|c|c|c|}
\hline $\begin{array}{l}\text { Model one } \\
\text { demographics } \\
\text { Coefficients }\end{array}$ & Estimate & Standard error & $\mathrm{t}$ value & Probability $>[\mathrm{T}]$ \\
\hline Intercept & 0.586896 & 0.199836 & 2.937 & 0.00405 \\
\hline age & 0.007027 & 0.003243 & 2.167 & 0.03242 \\
\hline $\operatorname{sex}$ & 0.203797 & 0.087865 & -2.319 & 0.02224 \\
\hline Packet years smoked & 0.002604 & 0.001627 & 1.600 & 0.11243 \\
\hline \multicolumn{5}{|l|}{$\begin{array}{l}\text { Multiple R-squared: } \\
0.1073 \text {, Adjusted R- } \\
\text { squared: } 0.07451 \\
\text { F-statistic: } 3.274 \text { on } 4 \\
\text { and } 109 \text { DF, } p= \\
0.01412\end{array}$} \\
\hline $\begin{array}{l}\text { Model Two clinical } \\
\text { factors } \\
\text { Coefficients }\end{array}$ & Estimate & Standard error & $\mathrm{t}$ value & Probability $>[\mathrm{T}]$ \\
\hline Intercept & 1.06890 & 0.05197 & 20.57 & $<2 \mathrm{e}-16$ \\
\hline Asthma & -0.25457 & 0.09123 & -2.79 & 0.00619 \\
\hline \multicolumn{5}{|l|}{$\begin{array}{l}\text { Multiple R-squared: } \\
0.065 \text {, Adjusted R- } \\
\text { squared: } 0.05666 \\
\text { F-statistic: } 7.787 \text { on } 1 \\
\text { and } 112 \text { DF, } \\
p=0.006188\end{array}$} \\
\hline $\begin{array}{l}\text { Combined model } \\
\text { Coefficients }\end{array}$ & Estimate & Standard error & $\mathrm{t}$ value & Probability $>[\mathrm{T}]$ \\
\hline Intercept & 0.788732 & 0.238309 & 3.310 & 0.00127 \\
\hline age & 0.004731 & 0.003588 & -2.078 & 0.04003 \\
\hline sex & -0.18289 & 0.087999 & -2.078 & 0.04003 \\
\hline Packet years smoked & 0.002361 & 0.001627 & 1.451 & 0.14972 \\
\hline Asthma & $\begin{array}{l}- \\
0.158238 \\
\end{array}$ & 0.103480 & -1.529 & 0.12912 \\
\hline $\begin{array}{l}\text { Multiple R-squared: } \\
0.1185 \text {, Adjusted R- } \\
\text { squared: } 0.08619 \\
\text { F-statistic: } 3.664 \text { on } 4 \\
\text { and } 109 \text { DF, } \\
p=0.007699\end{array}$ & & & & \\
\hline
\end{tabular}


medRxiv preprint doi: https://doi.org/10.1101/2020.07.26.20162248; this version posted July 29, 2020. The copyright holder for this preprint

(which was not certified by peer review) is the author/funder, who has granted medRxiv a license to display the preprint in perpetuity.

\section{Supplementary Methods}

\section{Detailed qPCR methods}

In the Newcastle cohort, total mRNA was extracted from ALI cultures using RNeasy mini kit (Qiagen, Germany) following the manufacturer's instructions and RNA quality and quantity was measured using nano-drop 2000 spectrophotometer (Thermo Scientificтм). A total of 200ng mRNA from each sample was used to synthesise cDNA using high-capacity cDNA reverse transcription kits (Applied BiosystemsTM). qPCR was performed using a Quanstudio $^{\text {TM }} 7$ Flex as per manufacturer's instructions using TaqMan ${ }^{\circledR}$ gene expression assays (ThemoFisher Scientific, Australia) and normalized to the18s housekeeping gene(52) (Table 2).

In the Perth cohort, RNA was extracted using PureLink® RNA (Life Technologies) as per manufacturer's instructions. Total RNA was then eluted with $40 \mu \mathrm{L}$ RNase free water and purity and yield was determined using a NanoDrop. Gene expression was analyzed by two-step reverse transcriptase-polymerase chain (RT-PCR) reactions. cDNA was synthesized using random hexamers and Multiscribe Reverse Transcriptase (Applied Biosystems, Foster City, CA) under the following conditions: $25{ }^{\circ} \mathrm{C}$ for $10 \mathrm{~min}, 48$ for $60 \mathrm{~min}$ and $95{ }^{\circ} \mathrm{C}$ for 5 min. Expression of target and housekeeping genes were then assessed via real time qPCR, performed using a Quanstudio ${ }^{\text {TM }} 7$ Flex as per manufacturer's instructions. Pre-designed Taqman $^{\mathrm{TM}}$ primer/probes with fluorescein amidite (FAM) labels are listed in Table 2. A $10 \mu 1$ final reaction containing $2.5 \mu 1$ cDNA template, $5 \mu 1$ Taqman ${ }^{\mathrm{TM}}$ Universal PCR Master Mix buffer and $0.5 \mu \mathrm{L}$ of Taqman ${ }^{\mathrm{TM}}$ primer/probes and RNase-free water was then prepared for each sample in duplicate. Expression of target genes was determined as $\Delta \Delta \mathrm{CT}$ values. 
medRxiv preprint doi: https://doi.org/10.1101/2020.07.26.20162248; this version posted July 29,2020 . The copyright holder for this preprint (which was not certified by peer review) is the author/funder, who has granted medRxiv a license to display the preprint in perpetuity.

\section{Immunohistochemistry}

Tissue sections underwent antigen retrieval by boiling in Tris-EDTA pH.9 for 20 minutes, and blocked using Background Sniper (Biocare Medical) for 1 hour before incubation with primary antibody at $4^{\circ} \mathrm{C}$ overnight in $0.5 \%$ TritonX-100 in PBS with $5 \%$ donkey serum. Primary antibodies included anti-ACE2 (Abcam; ab15348, 1:800), anti-acetylated tubulin (Sigma; 6-11B-1), and anti-E-cadherin (Cell Signaling; 4A2). Anti-rabbit and anti-mouse fluorophore-conjugated (Alexa Fluor 488 and Alexa Fluor 594) secondary antibodies were incubated with tissue sections for 1 hour at room temperature. Nuclei were visualized by Hoechst (Invitrogen). Images were captured with a Zeiss Axiovert 200 microscope with an Axiocam MRM digital camera. Antigen staining was quantified by blinded counting of the number of positively stained epithelial cells as a percentage of total epithelial cells. 
medRxiv preprint doi: https://doi.org/10.1101/2020.07.26.20162248; this version posted July 29,2020 . The copyright holder for this preprint (which was not certified by peer review) is the author/funder, who has granted medRxiv a license to display the preprint in perpetuity.

All rights reserved. No reuse allowed without permission.

\section{Supplementary Table 1}

\begin{tabular}{|l|l|l|l|}
\hline Gene & Catalogue number & TaqMan Assay ID & Dye-Probe \\
\hline ACE2 & 4331182 & Hs01085333_m1 & FAM-MGB \\
\hline TMPRSS2 & 4331182 & Hs01120965_m1 & FAM-MGB \\
\hline TMPRSS11A & 4331182 & Hs00699550_m1 & FAM-MGB \\
\hline TMPRSS11D & 4331182 & Hs00975370_m1 & FAM-MGB \\
\hline ADAM10 & 4331182 & Hs00153853_m1 & FAM-MGB \\
\hline ADAM17 & 4331182 & Hs01041915_m1 & FAM-MGB \\
\hline FURIN & 4331182 & Hs00159829_m1 & FAM-MGB \\
\hline CTSL & 4331182 & Hs00964650_m1 & FAM-MGB \\
\hline PI4KB & 4331182 & Hs00356327_m1 & FAM-MGB \\
\hline GRP78 & 4331182 & Hs99999174_m1 & FAM-MGB \\
\hline 18s & $4319413 E$ & & VIC-MGB \\
\hline
\end{tabular}


medRxiv preprint doi: https://doi.org/10.1101/2020.07.26.20162248; this version posted July 29,2020 . The copyright holder for this preprint (which was not certified by peer review) is the author/funder, who has granted medRxiv a license to display the preprint in perpetuity. All rights reserved. No reuse allowed without permission. 

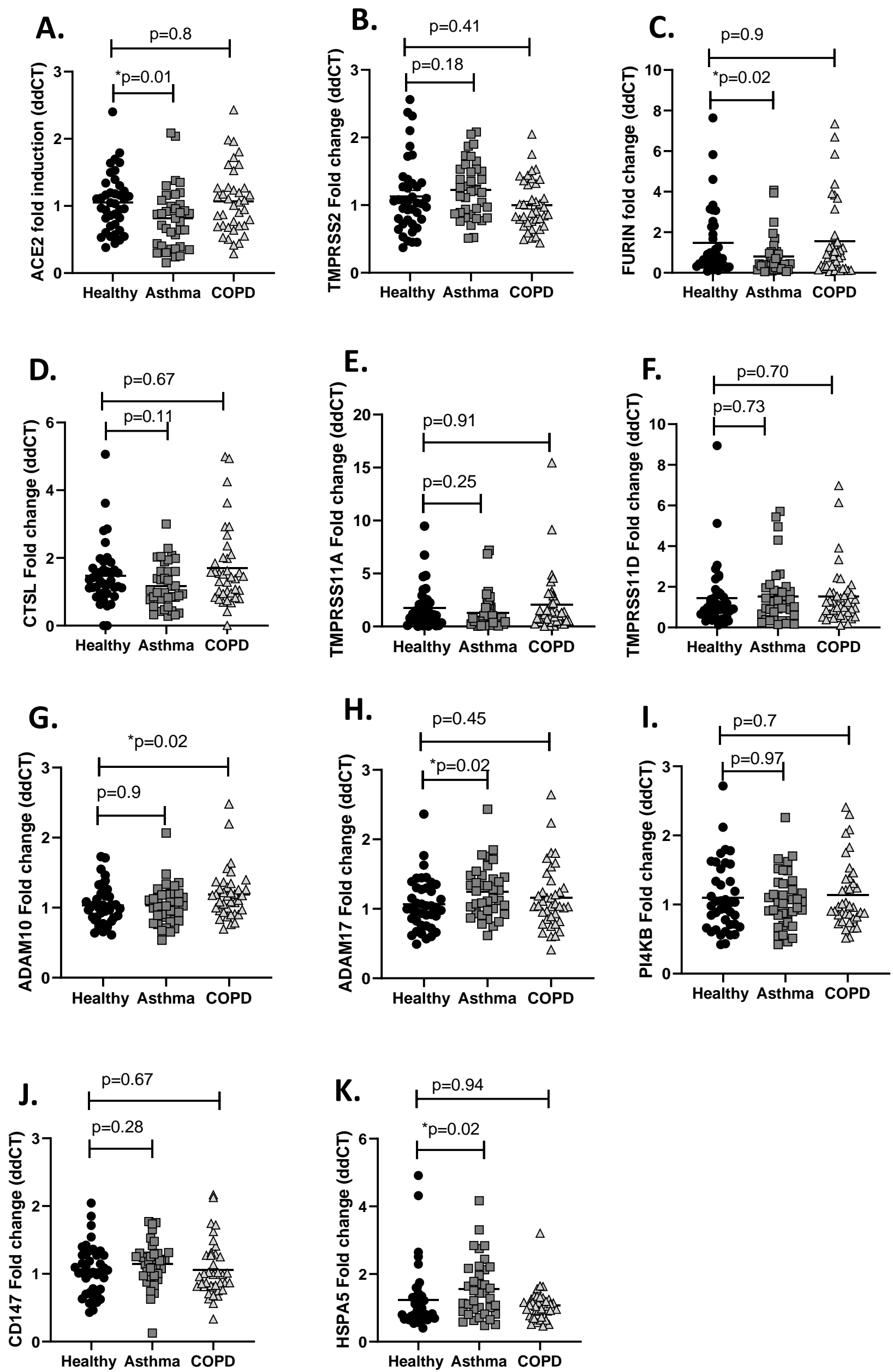

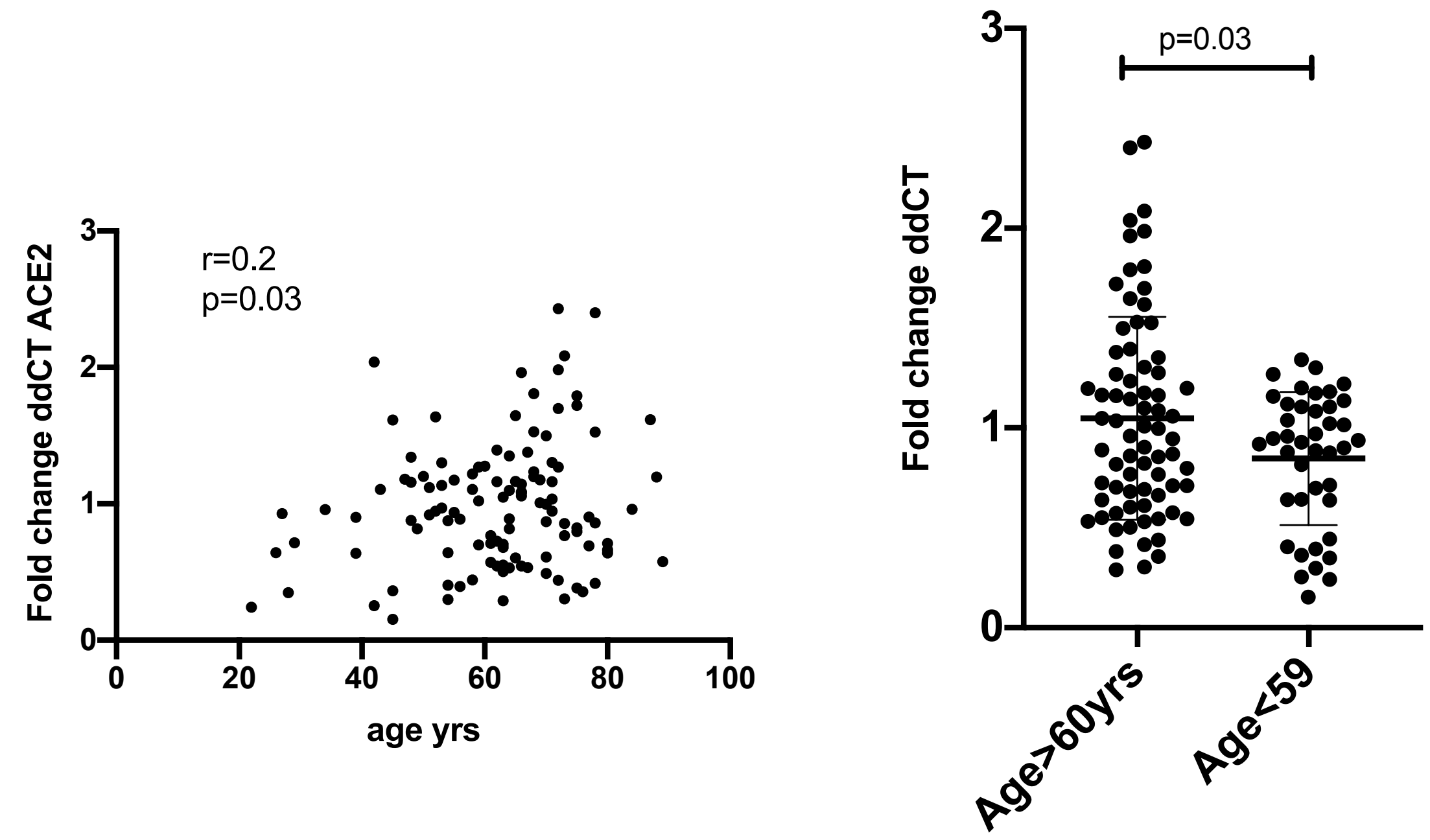


$$
p=0.01
$$

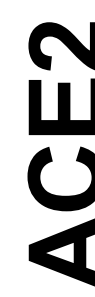

능

응

(1)

$\frac{\frac{1}{6}}{0}$

0

L
3

2

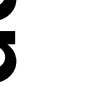

(2)

0

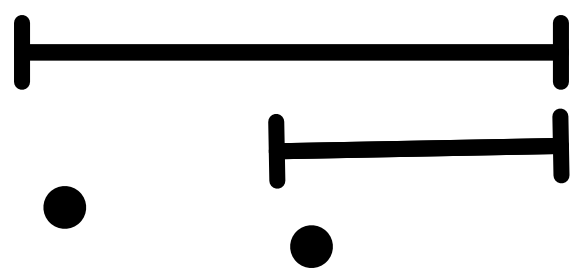

$\bullet$
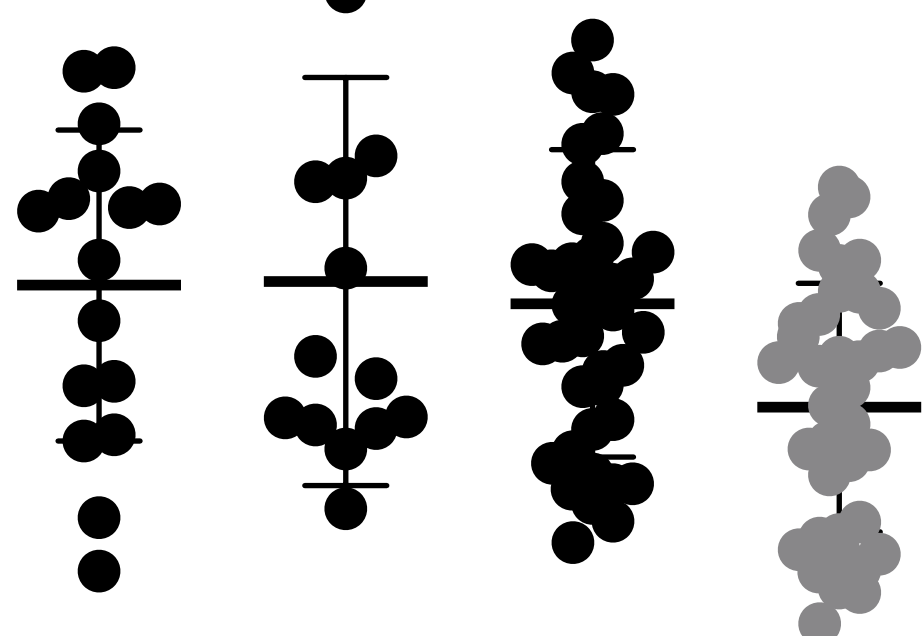

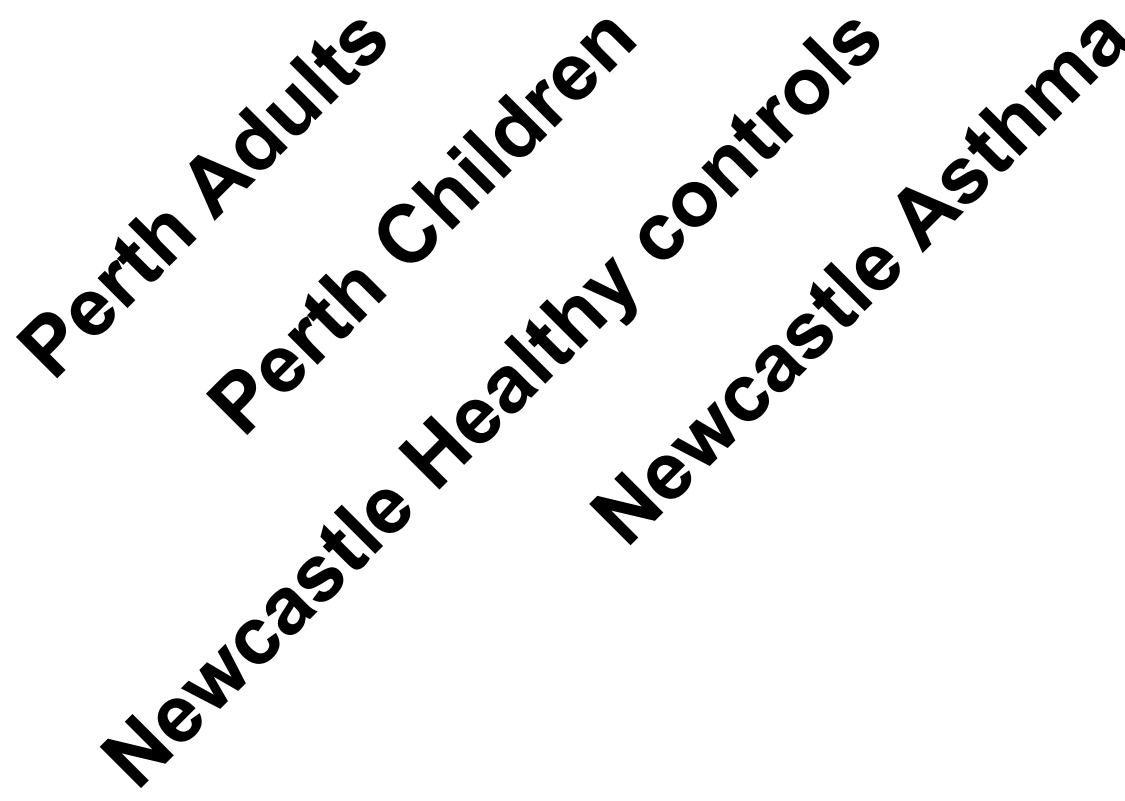


A Health control younger (42 years old)

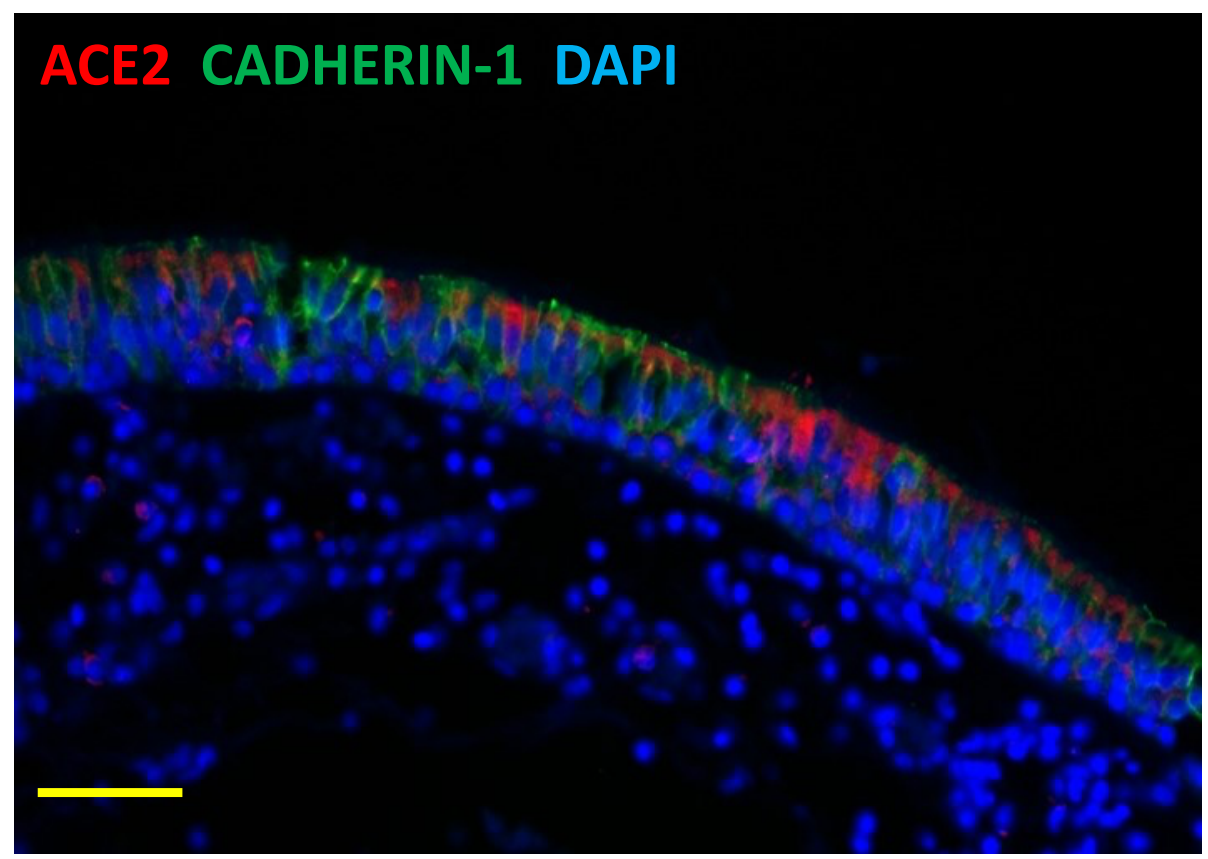

C

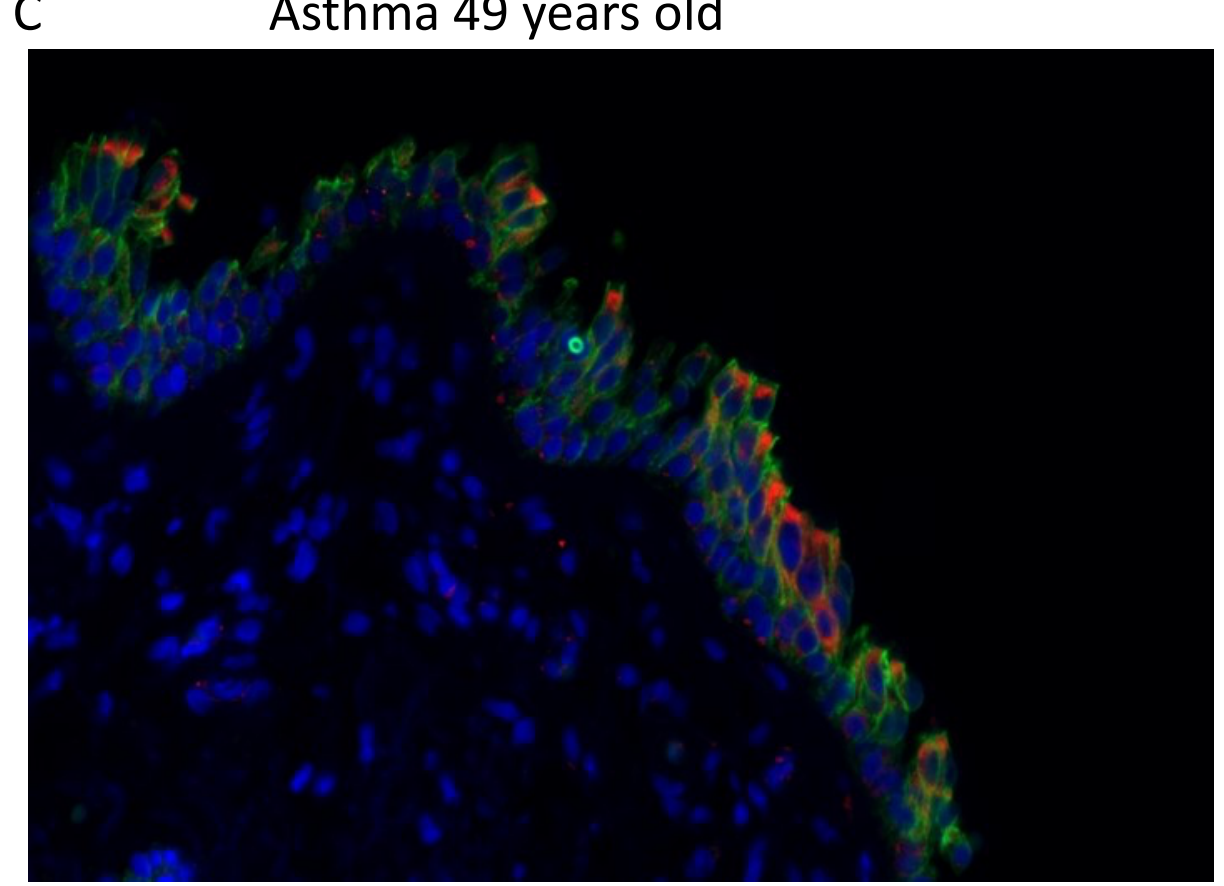

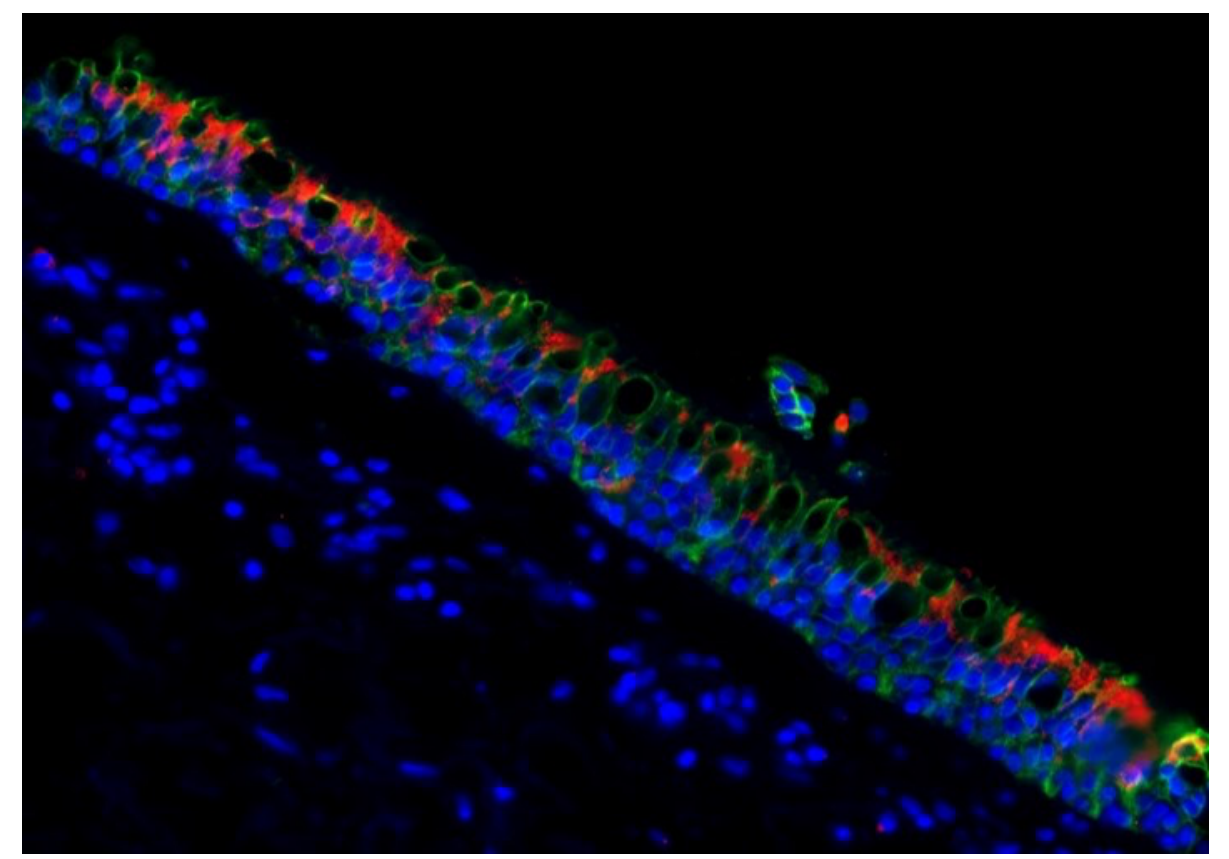




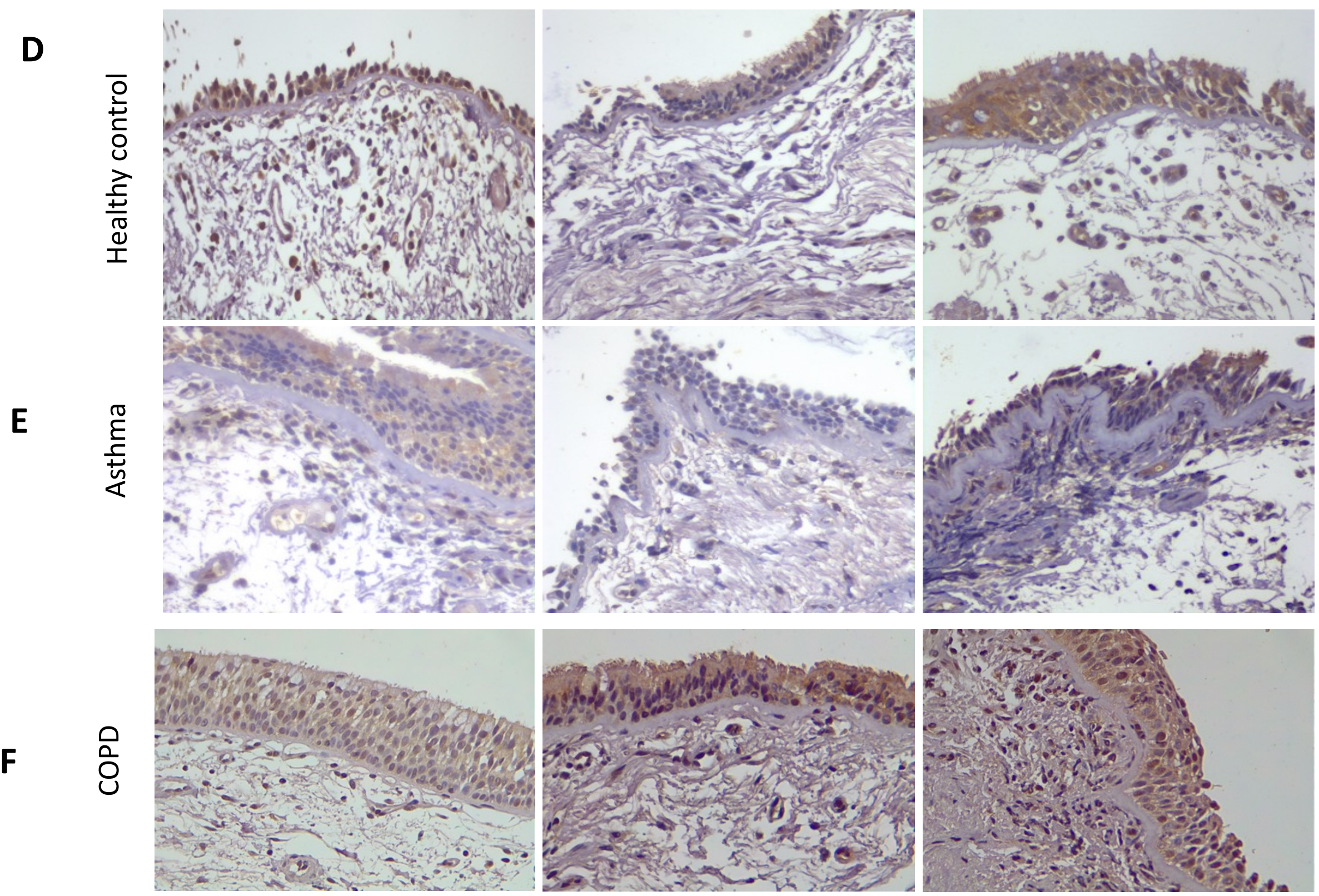

